\title{
Extended geographic distribution of several Indo-Pacific coral reef diseases
}

\author{
E. Weil ${ }^{1, *}$, A. Irikawa ${ }^{2}$, B. Casareto ${ }^{2}$, Y. Suzuki ${ }^{2}$ \\ ${ }^{1}$ Department of Marine Sciences, University of Puerto Rico, Call Box 9000, Mayaguez, Puerto Rico 00681, USA \\ ${ }^{2}$ Graduate School of Science and Technology, Environmental Science Section, Shizuoka University, 836 Ohya, Shizuoka-ku, \\ Shizuoka 422-8529, Japan
}

\begin{abstract}
Other than coral bleaching, few coral diseases or diseases of other reef organisms have been reported from Japan. This is the first report of lesions similar to Porites ulcerative white spots (PUWS), brown band disease (BrB), pigmentation response (PR), and crustose coralline white syndrome (CCWS) for this region. To assess the health status and disease prevalence, qualitative and quantitative surveys (3 belt transects of $100 \mathrm{~m}^{2}$ each on each reef) were performed in March and September 2010 on 2 reefs of the Ginowan-Ooyama reef complex off Okinawa, and 2 protected reefs off Zamani Island, in the Kerama Islands $40 \mathrm{~km}$ west of Okinawa. Overall, mean $( \pm \mathrm{SD})$ disease prevalence was higher in Ginowan-Ooyama $(9.7 \pm 7.9 \%)$ compared to Zamami $(3.6$ $\pm 4.6 \%$ ). Porites lutea was most affected by PUWS at Ooyama (23.1 \pm 10.4 vs. $4.5 \pm 5.2 \%)$. White syndrome (WS) mostly affected Acropora cytherea (12. $5 \pm 18.0 \%$ ) in Zamami and Oxipora lacera $(10.2 \pm 10 \%)$ in Ooyama. Growth anomalies (GA) and BrB were only observed on A. cytherea (8.3 $\pm 6.2 \%)$ and $A$. nobilis $(0.8 \%)$ at Zamami. Black band disease affected Pachyseris speciosa $(6.0 \pm$ $4.6 \%$ ) in Ooyama only. Pigmentation responses (PR) were common in massive Porites in both localities (2.6 \pm 1.9 and $5.6 \pm 2.3 \%$ respectively). Crustose coralline white syndrome (CCWS) was observed in both localities. These results significantly expand the geographic distribution of PUWS, BrB, PR and CCWS in the Indo-Pacific, indicating that the northernmost coral reefs in the western Pacific are susceptible to a larger number of coral diseases than previously thought.
\end{abstract}

KEY WORDS: Japan - Northern Pacific $\cdot$ Brown band disease Porites ulcerative white spots White syndrome $\cdot$ Growth anomalies

\section{INTRODUCTION}

Diseases of corals and other reef organisms are more commonly found in tropical regions, where their impact has increased in recent decades (Green \& Bruckner 2000, Weil 2004, Willis et al. 2004, Sutherland et al. 2004, Weil et al. 2006, Harvell et al. 2007, 2009, Weil \& Rogers 2011). Over the last $30 \mathrm{yr}$, coral diseases have been responsible for significant mortalities and coral community structure changes in many Caribbean and Indo-Pacific tropical coral reefs
(Gladfelter 1982, Willis et al. 2004, Miller et al. 2006, 2009, Weil et al. 2009). Only a few of the common damaging coral diseases of the tropics have been reported from the northern- and southernmost coral reef communities in both the Atlantic-Caribbean (Weil et al. 2002, Weil 2004, Francini-Filho et al. 2008, Cróquer \& Weil 2009), and the Indo-Pacific (Yamashiro et al. 2000, Yamashiro 2004, Irikawa 2006, Irikawa et al. 2011, Dalton \& Smith 2006).

The most developed and diverse coral reefs of Japan are located in 3 groups of islands which form 
the central and southern part of the Ryukyu archipelago $\left(<27^{\circ} \mathrm{N}\right)$, which lies to the south of the main islands of Japan (see Fig. 1). Scleractinian corals however, are found all the way north to Tokyo Bay $\left(35^{\circ} \mathrm{N}\right.$ latitude), and the number of coral species for Japan is estimated at around 415 (Nishihira 2004), a high level of biodiversity for sub-tropical and temperate conditions. These highly diverse and extensive coral communities thrive at this northern latitude mostly due to the warm waters of the Kuroshio current flowing from the south (Nishihira 2004). Changes in seasonal sea surface temperatures (SST) can influence the virulence of potential coral pathogens (Kimes et al. 2011), while thermal stress seems to be the major driver of coral bleaching and may trigger the emergence and spread of new biotic coral diseases (Harvell et al. 1999, 2002, 2009, Hoegh-Guldberg 1999, Bruno et al. 2007, Weil et al. 2009). The current trend of global increase in sea water temperatures may bring warmer than normal waters to these northern localities via the Kuroshio current, spreading tropical pathogens and/or inducing more diseases among Japan's coral reefs in the near future, and potentially threatening their biodiversity and productivity.

The bleaching event of 1980 is the oldest record of an environmentally induced disease on Japanese coral reefs (Yamazato 1981). Since then, bleaching has been a recurrent event on many reefs (Nakano 2004). Growth anomalies (GA) affecting several species of tabulate Acropora, Porites and Montipora were the first reported coral diseases potentially caused by biotic factors (Yamashiro et al. 2000, Irikawa 2006, Irikawa et al. 2011) (see Table 1). A condition called Porites pink block disease (PPBD) was later reported to be expanding around the Ryukyu archipelago (Yamashiro 2004), and was attributed to a trematode similar to the one described for massive Porites (trematodiasis) in Hawaii (Aeby 1998). In the last $5 \mathrm{yr}$, black band disease (BBD) and white syndrome (WS) have been observed, producing significant tissue loss in tabulate acroporids, Montipora sp. and Pachyseris sp. in several southern reef localities (Casareto 2008, A. Irikawa pers. obs.). More recently, focal bleaching (bleached spots over the coral surface termed 'white spot syndrome'), was reported in Turbinaria peltata from Oshima Island, a northern temperate locality, where corals do not grow large or fast enough to form reefs (Yamashiro \& Fukuda 2009). Here we present a summary of qualitative observations and quantitative surveys for 2 reef localities in the central part of the Ryukyu archipelago.

\section{MATERIALS AND METHODS}

To assess number of diseases, species affected, and prevalence of diseases affecting corals and other important benthic components (e.g. soft corals, sponges, crustose coralline algae), qualitative observations were made during the spring (March 2010), and quantitative surveys were conducted during the summer (September 2010) at 2 localities in the Ryukyu Island system: (1) the unprotected Ginowan-Ooyama deep reef complex (17 to $45 \mathrm{~m}$ deep) located near Naha city, Okinawa, and (2) the Zamami reefs, located $40 \mathrm{~km}$ west of Naha in the Kerama Islands, a Marine Protected Area (MPA) with low human impact (Fig. 1). Two reefs were surveyed in each of the 2 localities. In the Ginowan-Ooyama complex, 2 spur and groove formations $\left(26^{\circ} 17.91^{\prime} \mathrm{N}, 127^{\circ} 43.30^{\prime} \mathrm{E}\right.$ and $26^{\circ} 17.86^{\prime} \mathrm{N}$, $\left.127^{\circ} 43.28^{\prime} \mathrm{E}\right)$ were surveyed. In Zamami, we surveyed Amuro reef, a fringing structure extending down to $30 \mathrm{~m}\left(26^{\circ} 12.09^{\prime} \mathrm{N}, 127^{\circ} 19.25^{\prime} \mathrm{E}\right)$, and Maehama, a series of large patch reefs growing over sandy substrate from 1 to $15 \mathrm{~m}$ deep $\left(26^{\circ} 12.06^{\prime} \mathrm{N}, 127^{\circ} 16.72^{\prime} \mathrm{E}\right)$.

In March 2010, a $1 \mathrm{~h}$ SCUBA dive was conducted at each reef. Starting at the base of the reef (or $25 \mathrm{~m}$ maximum depth), and slowly swimming up in a long zig-zag pattern following the contour of the reef, colonies were carefully checked in as many habitats as possible, tallied, and photographed when disease signs, uncommon coloration patterns, lesions or scars were observed. Soft corals and crustose coralline algae (CCA) were also checked during these surveys. A qualitative assessment of relative disease abundance was produced from these observations and categorized as 'relatively abundant' ( $>10 \%$ of colonies affected) 'intermediate abundance' (5 to $10 \%$ colonies affected), or 'rare' $(<3 \%$ of colonies affected) (see Table 1). Then, in September 2010, three $50 \times 2 \mathrm{~m}\left(100 \mathrm{~m}^{2}\right)$ belt transects $(\mathrm{n}=6$ per locality) were deployed between 7.4 and $9.6 \mathrm{~m}$ deep on each of the Zamani reefs and between 9.6 and $10.5 \mathrm{~m}$ deep on each of the Ginowan-Ooyama spur-andgroove reefs to assess and compare disease prevalence between the 2 localities. All coral colonies of the dominant species were checked along each transect for disease, bleaching, predation and any other health problem signs (e.g. discolorations or pigmentation responses, tissue sloughing, spots). Diseases and other conditions were identified using guides by Beeden et al. (2008) and Raymundo et al. (2008), and corroborated by sending high definition photographs to expert colleagues in the region. Data were tallied, 


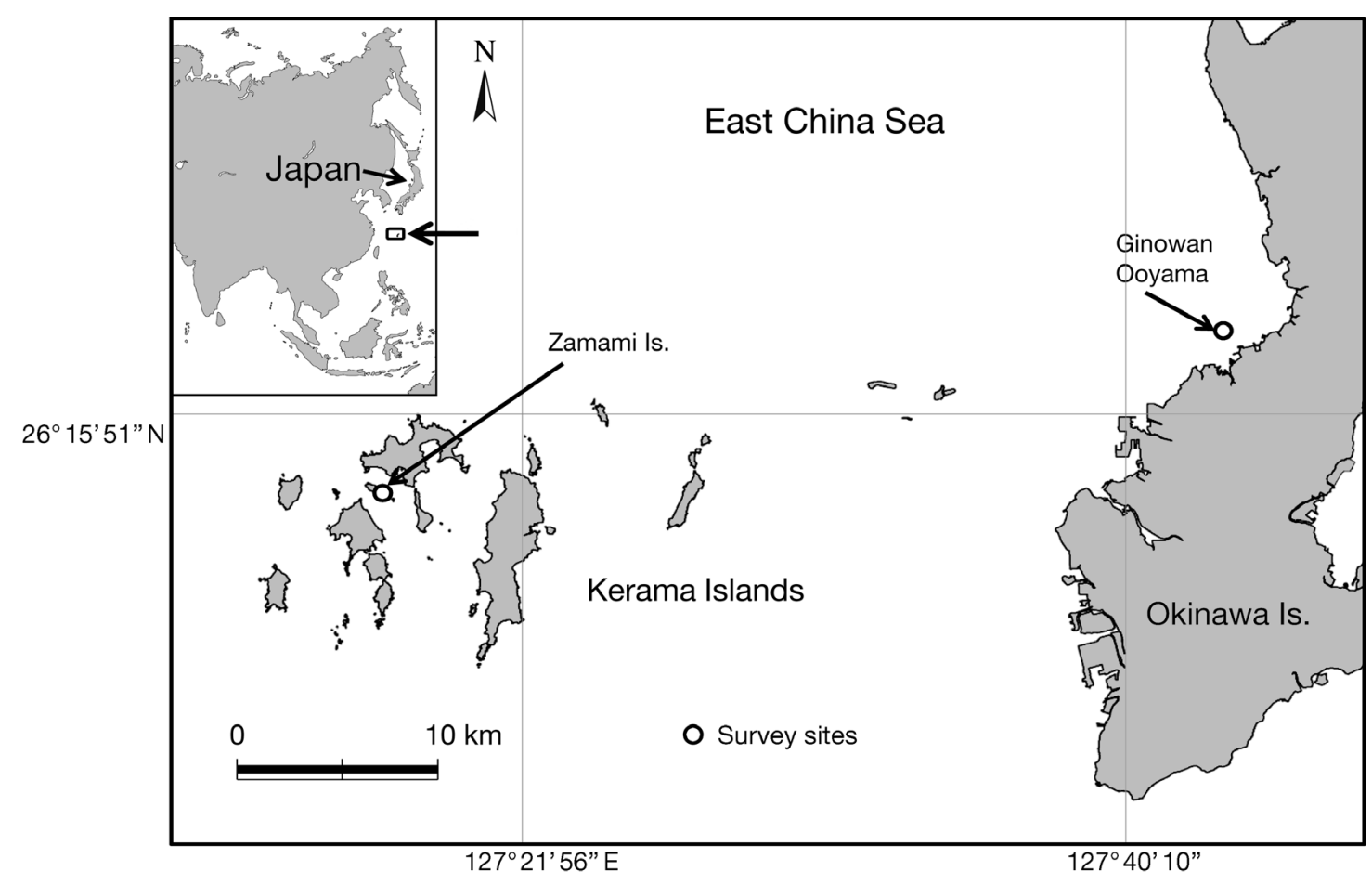

Fig. 1. Location of the Ryukyu Islands (inset) in the northwestern Pacific and the sampled reef localities. The GinowanOoyama reef complex, which is not protected, is near Okinawa's capital city, Naha. Zamani Island is located in the Kerama Islands Marine Park Area, $40 \mathrm{~km}$ west of Okinawa

transformed (arcsin) and analyzed using ANOVA to assess significant differences in total community prevalence, and prevalence of the major disease problems found.

\section{RESULTS AND DISCUSSION}

A higher than expected number of coral colonies were observed with disease signs during the spring 2010 surveys, when water temperatures were in the low 20s $\left(20\right.$ to $\left.23^{\circ} \mathrm{C}\right)$. Many colonies of Porites lutea and $P$. lobata had signs of active PUWS in all 4 reefs surveyed (Fig. 2A, $\mathrm{B}$, Table 1). This is a new disease record for Japan and the northernmost report for this disease, which significantly expands its known geographic distribution. During the summer, population prevalence levels (mean $\pm \mathrm{SD}$ ) of PUWS in P. lutea were significantly higher $(\mathrm{p}<0.05)$ at GinowanOoyama $(23.1 \pm 10.4 \%)$, compared to Zamami $(4.5 \pm$ $5.2 \%$ ) (Table 2, Fig. 3). The disease is characterized by a multifocal pattern of small, white and ovoid bleached or tissue-clean lesions exposing bare skeleton (Raymundo et al. 2003, 2008). This condition was first observed in the Philippines in 1996 and charac- terized in 2003 (Raymundo 2001, Raymundo et al. 2003). PUWS affects up to 11 species of Porites (a few colonies of Goniastrea sp., Echinopora sp., and Favia sp. have also been observed with similar signs), and prior to the present study, its known geographic distribution had been limited to tropical localities: the Philippines, Guam, Palau, Great Barrier Reef, Indonesia, Tanzania and Kenya (Willis et al. 2004, Raymundo et al. 2005, Weil \& Jordán-Dahlgren 2005, Haapkyla et al. 2009, Myers \& Raymundo 2009, E. Weil pers. obs.).

Surveyed colonies in Japan showed the characteristic white spots of PUWS in different phases, including bleached tissue, coalesced spots, exposed clean skeleton (no tissue), and old lesions already colonized by filamentous algae (Fig. 2A,B). The number of disease focal spots varied significantly from a few in some colonies to hundreds in some medium-sized colonies (500 to $1000 \mathrm{~cm}^{2}$ ). Colonies observed with larger dead round areas ( 2 to $5 \mathrm{~cm}^{2}$ ) already colonized by filamentous algae might indicate that this disease has been present for some time.

Pink round spots were observed in many colonies of massive Porites in both localities, some of them also with PUWS-like signs (Table 1, Fig. 2C). This is 


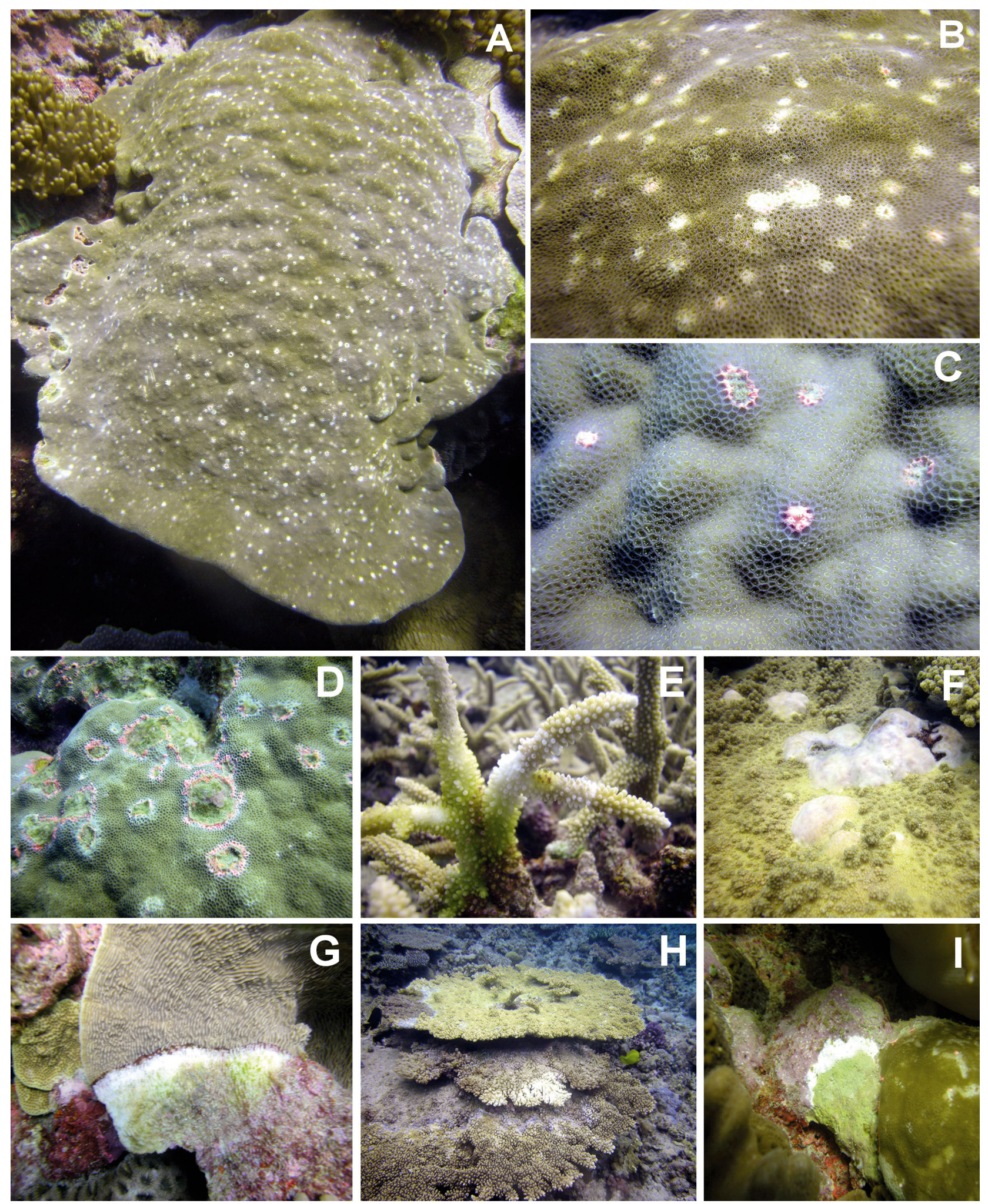

Fig. 2. Previously reported and newly observed coral reef diseases on Japanese reefs. (A,B) Colonies of Porites lutea showing signs of Porites ulcerative white spots (PUWS). (C,D) Pigmentation responses expressed as pink spots and pink lines on Porites colonies. (E) Brown band-like disease signs on Acropora nobilis. (F) Growth anomalies on Acropora cytherea. (G) Black band disease on Pachyseris speciosa. (H) White syndrome on Acropora florida. (I) Crustose coralline white syndrome on an unidentified coralline algae. Photos: E. Weil 
Table 1. Summary of coral diseases, their relative abundance in spring $2010(+++:>10 \%$ of colonies affected; ++: 5 to $10 \%$ of colonies affected; $+:<3 \%$ of colonies affected) and number of localities (+++: many; ++: few; +: rare) reported from this and other studies in Japan. The column 'Potential cause' includes information on potential pathogens and other causes identified in studies from other geographic localities which may not be listed in the source column and which need verification

\begin{tabular}{|c|c|c|c|c|c|}
\hline Disease condition & Abundance & Localities & $\begin{array}{l}\text { Geographic } \\
\text { distribution }\end{array}$ & $\begin{array}{l}\text { Potential } \\
\text { cause }\end{array}$ & Source \\
\hline $\begin{array}{l}\text { Porites ulcerative white } \\
\text { spots (PUWS) }\end{array}$ & +++ & ++ & Indo-Pacific & Vibrio spp. & Present study \\
\hline Pigmentation response (PR) & +++ & ++ & Indo-Pacific & Unknown & Present study \\
\hline Brown band disease (BrB) & + & + & Indo-Pacific & Ciliate & Present study \\
\hline Growth anomalies (GA) & ++ & +++ & Indo-Pacific & $\begin{array}{l}\text { Fungi, endolithic algae, } \\
\text { virus, aging }\end{array}$ & $\begin{array}{l}\text { Yamashiro (2004), Irikawa } \\
(2006), \text { Irikawa et al. (2011) }\end{array}$ \\
\hline Black band disease (BBD) & ++ & ++ & Indo-Pacific & Cyanobacterial mat & $\begin{array}{l}\text { Yamashiro (2004), } \\
\text { Irikawa (2006) }\end{array}$ \\
\hline White syndrome (WS) & ++ & ++ & Indo-Pacific & Vibrio spp., apoptosis & $\begin{array}{l}\text { Ainsworth et al. (2007), } \\
\text { Casareto (2008), } \\
\text { Sussman et al. (2008) }\end{array}$ \\
\hline $\begin{array}{l}\text { Compromised health } \\
\text { conditions }(\mathrm{CH})\end{array}$ & ++ & +++ & Indo-Pacific & $\begin{array}{l}\text { Environmental/ } \\
\text { biological stressors }\end{array}$ & Present study \\
\hline $\begin{array}{l}\text { Porites pink block disease } \\
\text { (PPBD) (trematodiasis?) }\end{array}$ & ++ & ++ & Hawaii & $\begin{array}{l}\text { Trematode larvae } \\
\text { (Podocotyloides sp.) }\end{array}$ & Yamashiro (2004) \\
\hline Bleaching (BL) & ++ & +++ & Indo-Pacific & Environmental stressors & Yamazato (1981) \\
\hline White spots (focal bleaching) & + & + & Indo-Pacific & Environmental stressors? & Yamashiro \& Fukuda (2009) \\
\hline $\begin{array}{l}\text { Crustose coralline white } \\
\text { syndrome (CCWS) }\end{array}$ & ++ & ++ & Indo-Pacific & Unknown & Present study \\
\hline Predation & ++ & ++ & Indo-Pacific & $\begin{array}{l}\text { Snails, crown-of-thorns } \\
\text { seastars }\end{array}$ & $\begin{array}{l}\text { Willis et al. (2004), Weil \& } \\
\text { Jordán-Dahlgren (2005), } \\
\text { present study }\end{array}$ \\
\hline
\end{tabular}

Table 2. Mean (SD) prevalence of coral diseases in 2 geographic localities in the Ryukyu archipelago, Japan. See Table 1 for disease abbreviations. -: disease not found

\begin{tabular}{|c|c|c|c|}
\hline $\begin{array}{l}\text { Disease } \\
\text { condition }\end{array}$ & Zamami & Ooyama & Species affected \\
\hline PUWS & $23.1(10.4)$ & $4.5(5.2)$ & $\begin{array}{c}\text { Porites lutea, } \\
\text { P. lobata }\end{array}$ \\
\hline PR (pink line) & $5.6(2.3)$ & $2.6(1.9)$ & $\begin{array}{c}\text { Porites lutea, } \\
\text { P. lobata }\end{array}$ \\
\hline $\mathrm{BrB}$ & - & $0.8(1.1)$ & Acropora nobilis \\
\hline GA & - & $8.33(6.2)$ & $\begin{array}{c}\text { Acropora cytherea } \\
\text { A. florida }\end{array}$ \\
\hline BBD & $3.3(3.2)$ & - & $\begin{array}{l}\text { Pachyseris } \\
\text { speciosa }\end{array}$ \\
\hline WS & $10.5(10)$ & $12.5(18)$ & $\begin{array}{c}\text { A. cytherea, } \\
\text { A. florida, } \\
\text { Oxypora lacera }\end{array}$ \\
\hline $\mathrm{CH}$ & $6.0(4.6)$ & - & Oxypora lacera \\
\hline Overall mean & $9.7(7.9)$ & $3.6(4.6)$ & \\
\hline
\end{tabular}

a pigmentation response that could result from physical and other stressors and that look like PUWS lesions, but larger, with a puffy gel-like, pink secretion (perhaps swollen tissue and/or mucus accumulation). These signs have been described as 'pink line' because they develop into pink ring-shaped lines bordering tissue-dead areas and are surrounded by healthy-looking tissues (Fig. 2C,D). The prevalence of this condition was higher among coral populations at the Ooyama reef complex compared to the Zamami reefs $(5.6 \pm 2.3$ vs. $2.6 \pm 1.9 \%$, respectively; Table 2, Fig. 3), and these signs were similar to those observed in Porites colonies in many localities throughout the Indo-Pacific. However, it is different from Porites pink block disease (PPBD) (possibly 'trematodiasis'?) described for some areas in the Ryukyu archipelago (Yamashiro 2004), and a similar condition produced by trematodes in $P$. compressa in Hawaii (Aeby 1998; our Table 1). No pathology has been described for this pigmentation response. This is the first report for Japan and the northernmost location, significantly expanding the known geographic distribution of this condition.

Characteristic signs of brown band disease (BrB) were observed in a few branches of a single colony of Acropora nobilis in the Kerama islands during the March 2010 surveys (Table 1, Fig. 2E). In September 2010, BrB prevalence at the population level was also very low $(0.8 \pm 1.1 \%)$. The presence of ciliates was verified by close and careful observation of the 


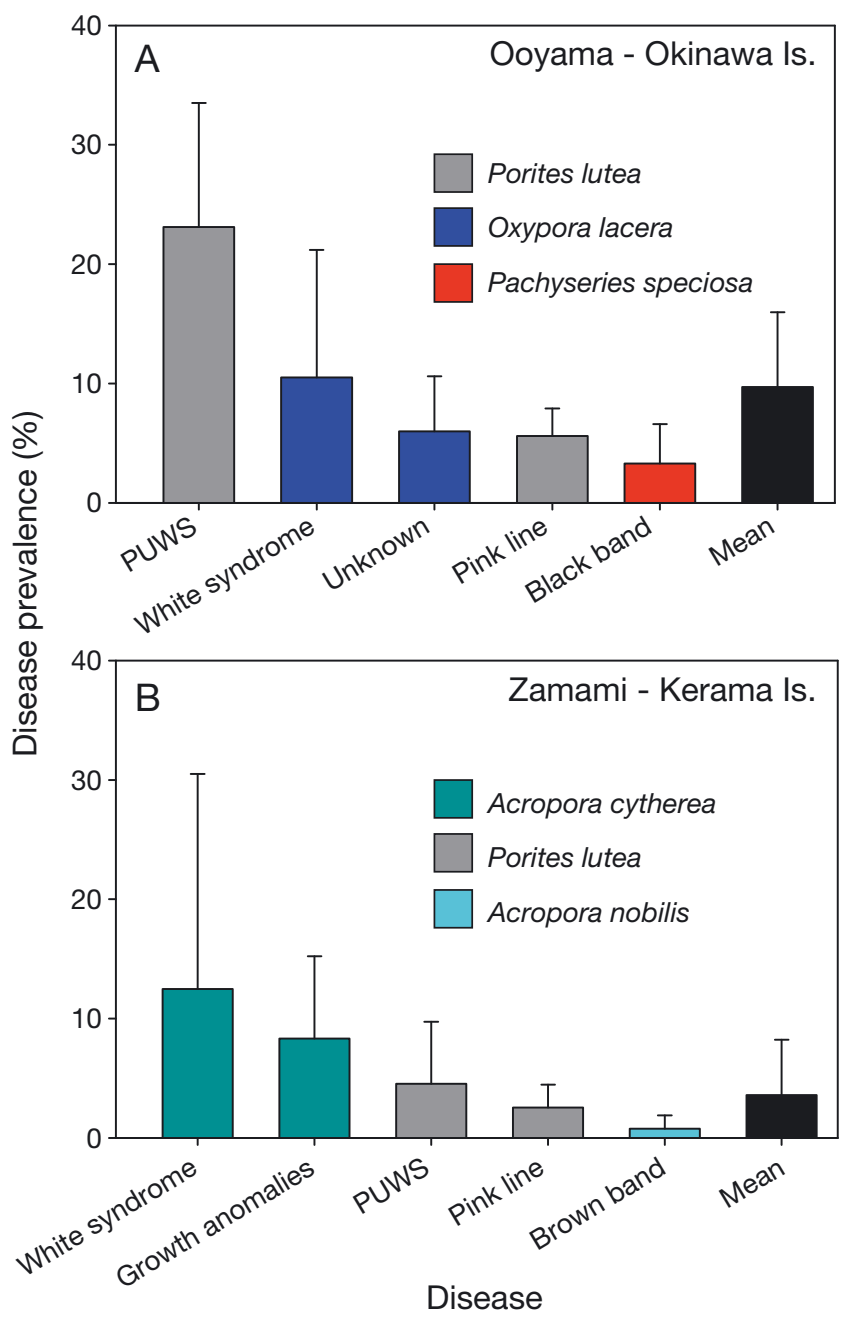

Fig. 3. Mean $(+\mathrm{SD})$ disease prevalence in the 2 localities. Colors correspond to main coral species affected. (A) Ginowan-Ooyama reefs. (B) Zamani reefs. Mean overall disease prevalence was significantly higher in the unprotected Ginowan-Ooyama reef complex near Naha compared to the Marine Park Area reefs off the Zamani Islands

affected area. This is the first report of this condition for Japan, significantly expanding the known geographic distribution of BrB in the western Pacific. The species of ciliate was not identified, but future collections are planned to characterize the pathology of this condition.

Growth anomalies (GA) affecting tabulate acroporids and Astreopora sp. were the most common disease condition in the Kerama islands (Fig. 2F, Table 1). Prevalence levels during the summer in Acropora cytherea were moderate and highly variable $(8.3 \pm 6.2 \%)$ (Table 2, Fig. 3). Colonies of Acropora nasuta and Acropora hyacinthus did not show any signs of diseases at the Zamani reefs. No colonies of Acropora were observed in the spur-and-groove reefs at the Ginowan-Ooyama complex. Large pale and bleached GA affecting massive colonies of Porites lobata and P. lutea, similar to those described for many reef localities in the Indo-Pacific (Raymundo et al. 2008, McClanahan et al. 2009), were not observed during these short surveys but, they have been reported for reefs in Okinawa and the Kerama islands (Yamashiro 2004) (Table 1).

Black band disease (BBD) was observed on several colonies of Pachyseris speciosa in Maehama reef during the March 2010 surveys. Prevalence levels in September were low $(3.3 \pm 3.2 \%)$ for this species on the same reefs. This condition was not observed in the Zamami reefs during either survey. The black bacterial mat was observed to be thin but it was advancing fast enough as to leave behind a white area of clean skeleton that will be eventually colonized by algae (Fig. 2G). This disease was previously reported with low prevalence for the Sekisei lagoon in the Ishigaki islands to the south (Yamashiro 2004).

White syndrome (WS)-like signs were observed affecting several colonies of Acropora florida (Fig. 2H) and Acropora cytherea in the Zamani reefs, and Oxypora lacera in the Ginowan-Ooyana complex. Summer WS prevalence levels in A. cytherea in Zamani were high and variable across transects $(12.5 \pm 18 \%)$, but similar to WS prevalence levels in $O$. lacera in Ooyama (10.5 $\pm 10.0 \%$ ) (Table 2, Fig. 3). Several colonies of massive Porites showed 'compromised health conditions' $(\mathrm{CH})$ characterized by irregular tissue paling and discoloration (from tan-brown to grayish and bluish) patterns, similar to those observed in many other Indo-Pacific localities (Weil \& JordánDahlgren 2005, Beeden et al. 2008, Raymundo et al. 2008); some colonies had extensive tissue mortality at the edges (Table 1). During the summer surveys, many colonies of $O$. lacera showed signs of an unknown $\mathrm{CH}$ characterized by irregular paling and bleached areas along the colonies, with tissue sloughing and mortality. Prevalence was $6.0 \pm 4.6 \%$ (Table 2 , Fig. 3) in the Ginowan-Ooyama complex. No colonies with this condition were observed in Zamami.

Other organisms observed with disease signs included the soft coral Lobophyton sp. which had several colonies with extensive bleached areas, loss of structure and areas with decomposing tissues. Several crusts of crustose coralline algae (CCA) were observed with thin ring-like white bands separating healthy looking tissues from dead areas (Fig. 2I), similar to those described as crustose coralline white syndrome (CCWS) in many localities in Caribbean and the Indo-Pacific (Weil 2004, Weil \& JordánDahlgren 2005, Ballantine et al. 2005, Weil et al. 
2006, Vargas-Angel 2010, Weil \& Rogers 2011), representing the first record of this condition for Japan and significantly expanding its known geographic distribution. Scars and irregular areas devoid of live tissue consistent with signs of recent predation by crown-of-thorns starfish Acanthaster planci and murex snails Drupella spp. were also observed in the reefs surveyed. Snails were found under the colonies or nearby, but sea stars were not observed.

The overall mean disease prevalence was higher in the Ginowan-Ooyama complex $(9.7 \pm 7.9 \%)$ compared to the protected Zamami Islands $(3.6 \pm 4.6 \%)$. There is little quantitative data on coral disease for Japan. The only area regularly monitored by the Japanese Environmental Agency has been the Sekisei Lagoon, at the Southern tip of the Ryukyu Archipelago, where 102 sites have been monitored since 2003. Results from these surveys showed significant increases in WS prevalence from $25.5 \%$ in 2003 to $91 \%$ in 2006 (killing large colonies of acroporids) and increased GA prevalence from 9.8 to $43.1 \%$ in the same period (Sato 2006). Prevalence levels of BBD were low and varied little in 3 yr (2.0 to $3.9 \%$ ). Prevalence of WS and GA in Zamami and the Ginowan-Ooyama reef complex (Table 2) were significantly lower in 2010.

Overall, our results indicate that the northernmost coral reefs in the Pacific are susceptible to a higher number of coral diseases than previously thought and that greater effort to investigate these phenomena must be made. This is especially true for the southernmost coral reefs of Japan which seem to be experiencing significant increases in the number and prevalence of some of the most damaging diseases in the Indo-Pacific region. Further research is needed to identify the putative pathogens for these conditions in Japan, their host ranges, virulence, vectors and reservoirs. Further and more frequent quantitative surveys are needed to compare the spatial distribution and variability of the different diseases, establish baseline prevalence levels for the most damaging conditions, characterize their seasonal dynamics, assess co-variation with environmental parameters, and the short and long term impact (e.g. mortality, loss of fecundity) each disease condition is having at the population level of the affected species, and at the coral community level in the different reef localities.

Acknowledgements. The University of Shizuoka supported E.W.'s visit to Japan and the surveys in Okinawa and the Kerama Islands. L. Raymundo, A. Hooten, G. Smith and 2 anonymous reviewers provided helpful comments and corrections that improved the manuscript. The Department of Marine Sciences, University of Puerto Rico provided release time to E.W. to develop this study.

\section{LITERATURE CITED}

Ainsworth TD, Kramasky-Winter E, Loya Y, HoeghGuldberg O, Fine M (2007) Coral disease diagnostics: What's between a plague and a band? Appl Environ Microbiol 73:981-992

Aeby GS (1998) A digenean metacercaria from the reef coral, Porites compressa, experimentally identified as Podocotyloides stenometra. J Parasitol 84:1259-1261

> Ballantine D, Weil E, Ruiz H (2005) Coralline white band syndrome, a coralline algal affliction in the Tropical Atlantic. Coral Reefs 24:117

Beeden R, Willlis BL, Raymundo LJ, Page CA, Weil E (2008) Underwater cards for assessing coral health on IndoPacific Reefs. Global Environment Fund Coral Reef Targeted Research (GEF-CRTR) Program, Currie Commission, Melbourne

Bruno JF, Selig ER, Casey KS, Page CA, Willis BL (2007) Thermal stress and coral cover as drivers of coral disease outbreaks. PLoS Biol 5:e124

Casareto BE (2008) Studies on water quality and bacteria composition in corals showing 'white syndrome' signs at Sekisei Lagoon, South Ishigaki Island, Okinawa, Japan. Lagoon 11:2-5

Cróquer A, Weil E (2009) Spatial variability in distribution and prevalence of coral and octocoral diseases in the Caribbean. II. Genera-level analysis. Dis Aquat Org 83:209-222

> Dalton SJ, Smith SDA (2006) Coral diseases dynamics at a subtropical location, Solitary Islands Marine Park, eastern Australia. Coral Reefs 25:37-45

Francini-Filho RB, Moura RL, Thompson FL, Reis RM, Kaufman L, Kikuchi RKP, Leão ZMAN (2008) Diseases leading to accelerated decline of reef corals in the largest South Atlantic reef complex (Abrolhos Bank, eastern Brazil). Mar Pollut Bull 56:1008-1014

Gladfelter WB (1982) White band disease in Acropora palmata: implications for the structure and growth of shallow reefs. Bull Mar Sci 32:639-643

Green EP, Bruckner AW (2000) The significance of coral disease epizootiology for coral reef conservation. Biol Conserv 96:347-361

Haapkylä J, Unsworth RKF, Seymour AS, MelbourneThomas J, Flavell M, Willis BL, Smith DJ (2009) Spatiotemporal coral disease dynamics in the Wakatobi Marine National Park, South-East Sulawesi, Indonesia. Dis Aquat Org 87:105-115

Harvell CD, Kim K, Burkholder JM, Colwell RR and others (1999) Emerging marine diseases-climate links and anthropogenic factors. Science 285:1505-1510

> Harvell CD, Mitchell CE, Ward JR, Altizer S, Dobson AP, Ostfeld RS, Samuel MD (2002) Climate warming and disease risks for terrestrial and marine biota. Science 296: 2158-2162

Harvell CD, Jordán-Dahlgren E, Merkel S, Rosenberg E and others (2007) Coral disease, environmental drivers and the balance between coral and microbial associates. Oceanography 20:172-195

> Harvell CD, Altize SR, Cattadori IM, Harrington L, Weil E (2009) Climate change and wildlife diseases: When does the host matter the most? Ecology 90:912-920

> Hoegh-Guldberg O (1999) Climate change, coral bleaching and the future of the world's coral reefs. Mar Freshw Res 50:839-866

Irikawa A (2006) A report on the prevalence of 'growth anomalies', a disease of hermatypic corals, in waters 
around Okinawa Islands, Japan. Lagoon 7:5-11 (in Japanese)

Irikawa A, Casareto BE, Suzuki Y, Hidaka M, van Woesik R (2011) Growth anomalies on Acropora cytherea corals. Mar Pollut Bull 62:1702-1707

Kimes NE, Grim CJ, Johnson WR, Hasan NA and others (2011) Temperature regulation of virulence factors in the pathogen Vibrio coralliilyticus. ISME J (in press) doi: 10.1038/ismej.2011.154

McClanahan TR, Weil E, Maina J, Lohr J (2009) Strong relationship between coral bleaching and 'tumors' in massive Porites. Glob Change Biol 15:1804-1816

Miller JR, Waara R, Muller E, Rogers CS (2006) Coral bleaching and disease combine to cause extensive mortality on corals reefs in US Virgin Islands. Coral Reefs 25:418

Miller JR, Muller E, Rogers CS, Waara R and others (2009) Coral disease following massive bleaching in 2005 causes $60 \%$ decline in coral cover on reefs in the US Virgin Islands. Coral Reefs 28:925-940

> Myers RL, Raymundo LJ (2009) Coral disease in Micronesian reefs: a link between disease prevalence and host abundance. Dis Aquat Org 87:97-104

Nakano Y (2004) Global environmental change and coral bleaching. In: Coral reefs of Japan. Ministry of Environment and the Japanese Coral Reef Society, Tokyo, p 42-48

Nishihira M (2004) Hermatypic corals of Japan. In: Coral reefs of Japan. Ministry of Environment and the Japanese Coral Reef Society, Tokyo, p10-19

Raymundo LJ (2001) Mediation of growth by conspecific neighbors and the effect of site in transplanted fragments of the coral Porites attenuata Nemenzo in the Central Philippines. Coral Reefs 20:263-272

Raymundo LJH, Harvell CD, Reynolds TL (2003) Porites ulcerative white spot disease: description, prevalence, and host range of a new coral disease affecting IndoPacific reefs. Dis Aquat Org 56:95-104

Raymundo LJ, Rosell KB, Reboton CT, Kaczmarsky L (2005) Coral diseases on Philippine reefs: genus Porites is a dominant host. Dis Aquat Org 64:181-191

Raymundo LJ, Couch CS, Harvell DC (eds) (2008) Coral disease handbook. Guidelines for assessment, monitoring and managing. GEF-CRTR Program, Currie Commission, Melbourne

Sato T (2006) A report on coral disease prevalence at the Sekisei Lagoon, Okinawa, Japan. Lagoon 9:13-14 (in Japanese)

Editorial responsibility: Garriet Smith, Aiken, South Carolina, USA
Sussman M, Willis BL, Victor S, Bourne DG (2008) Coral pathogens identified for white syndrome (WS) epizootics in the Indo-Pacific. PLoS One 3:e2393

Sutherland KP, Porter JW, Torres C (2004) Disease and immunity in Caribbean and Indo-Pacific zooxanthellate corals. Mar Ecol Prog Ser 266:273-302

> Vargas-Angel B (2010) Crustose coralline algal diseases in the US-affiliated Pacific Islands. Coral Reefs 29: 943-956

Weil E (2004) Coral reef diseases in the wider Caribbean. In: Rosenberg E, Loya Y (eds) Coral health and disease. Springer-Verlag, New York, NY, p 35-68

Weil E, Jordán-Dahlgren E (2005) Status of coral diseases in Zanzibar and Kenya, western Indian Ocean. Disease working group progress report, GEF-CRTR Program

Weil E, Rogers CS (2011) Coral reef disease in the AtlanticCaribbean. In: Dubinski Z, Stambler N (eds) Coral reefs: an ecosystem in transition. Springer-Verlag, Berlin, p 465-492

Weil E, Urreiztieta I, Garzón-Ferreira J (2002) Local and geographic variability in the incidence of disease in western Atlantic coral reefs. Proc 9th Int Coral Reef Symp, Bali 2:1231-1238

Weil E, Smith GW, Gil-Agudelo DL (2006) Status and progress in coral reef disease research. Dis Aquat Org 69:1-7

Weil E, Cróquer A, Urreiztieta I (2009) Temporal variability and consequences of coral diseases and bleaching in La Parguera, Puerto Rico from 2003-2007. Carib J Sci 45(2-3):221-246

Willis BL, Page CA, Dinsdale EA (2004) Coral disease on the Great Barrier Reef. In: Rosenberg E, Loya Y (eds) Coral health and disease. Springer-Verlag, New York, NY, p 69-104

Yamashiro H (2004) Coral diseases. In: Coral reefs of Japan. Ministry of Environment and the Japanese Coral Reef Society, Tokyo, p 56-59

Y Yamashiro H, Fukuda M (2009) White spot syndrome of Turbinaria peltata in the temperate region of Japan. Coral Reefs 28:893

Yamashiro H, Yamamoto M, van Woesik R (2000) Tumor formation on the coral Montipora informis. Dis Aquat Org 41:211-217

Yamazato K (1981) A note on the expulsion of zooxanthellae during summer, 1980 by the Okinawan reef building corals. Sesoko Lab Tech Rep 8:9-18

Submitted: June 9, 2011; Accepted: December 15, 2011 Proofs received from author(s): March 14, 2012 